\title{
Screening of Danish traffic cases for synthetic cannabinoids in whole blood by LC-MS/MS
}

\author{
Niels Bjerre Holm*, Rebeca Sequera Pineda' ${ }^{1}$ David Wederkinck Andersen ${ }^{1}$, Brian Schou Rasmussen ${ }^{1}$, \\ Petur Weihe Dalsgaard', Lotte C.G. Hoegberg², Sys Stybe Johansen', Kristian Linnet ${ }^{1}$
}

'Section of Forensic Chemistry, Department of Forensic Medicine, Faculty of Health Sciences, University of Copenhagen, Frederik V's Vej 11, 3. DK-2100, Denmark ${ }^{2}$ Department of Anaesthesiology, The Danish Poisons Information Center, Bispebjerg University Hospital, Bispebjerg Bakke 23, DK-2400, Denmark *Corresponding author: E-mail: niels.holm@sund.ku.dk

\begin{abstract}
A target screening method for the detection of 13 synthetic cannabinoids in whole blood was developed and validated. Samples underwent automated solid-phase extraction, and sample extracts were analyzed by liquid chromatography-positive electrospray ionization-tandem mass spectrometry using two transitions in multiple reaction monitoring mode. The limit of detection was between $0.1-2.5 \mathrm{ng} / \mathrm{mL}$ for the compounds except HU-210, and extraction recovery ranged from 59 to $78 \%$. The method was used to screen 393 Danish traffic cases from 2012, where the driver was suspected of driving under the influence of drugs. No synthetic cannabinoids were identified in these samples. Additionally, the method was applied to a clinical intoxication case, and the synthetic cannabinoid AM2201 was identified in serum. We conclude that the prevalence of driving under the influence of synthetic cannabinoids in Denmark is likely to be low, and that synthetic cannabinoids are most likely to be encountered in the clinical setting.
\end{abstract}

Keywords:

Forensic drug screening, driving under the influence of drugs, synthetic cannabinoids, clinical case, intoxication, AM-2201

\section{ABBREVIATIONS}

DUID - Driving under the influence of drugs,

LOD - Limit of detection,

MRM - Multiple reaction monitoring,

QC - Quality control

RE - Extraction recovery,

SPE - Solid-phase extraction,

THC $\quad-\Delta^{9}$-tetrahydrocannabinol

\section{INTRODUCTION}

Synthetic cannabinoids are defined by their ability to bind to the same receptors as the main naturally occurring, psychoactive constituent of cannabis, $\Delta^{9}$-tetrahydrocannabinol (THC), and are therefore also referred to as synthetic cannabinoid receptor agonists. The compounds were originally developed for medical research purposes, but have not progressed to clinical use due to undesirable psychoactive effects [1].

Synthetic cannabinoids were first identified as drugs of abuse in late 2008, when it became clear that herbal mixtures reported to have a marijuana-like effect (so-called "Spice" products) contained these compounds as adulterants [2,3]. The first identified synthetic cannabinoids were the C8 homolog of the cyclohexylphenol CP-47,497 and the aminoalkylindole JWH-018, but subsequently a vast number of compounds have been identified [4-6]. According to the yearly report from The European Monitoring Center for Drug and Drug Addiction (EMCDDA), 30 new synthetic cannabinoids have been identified by the EU Early warning system in 2012, which brings the total number of identified compounds by 2012 to more than 70 [7].
Given the rapid emergence of new compounds and the requirement for high sensitivity, most published methods for the detection of synthetic cannabinoids have been based on liquid-chromatography-mass spectrometry (LC-MS). This includes both quantitative and qualitative methods in whole blood [8,9], serum [10], oral fluid [11,12], as well as for metabolites in urine [13-15].

The pharmacokinetics has been investigated for a limited number of synthetic cannabinoids in humans. Following consumption of JWH-018 by inhalation, the serum concentrations reached maximum values of approximately $10 \mathrm{ng} / \mathrm{mL}$ within a few minutes, and dropped within $3 \mathrm{~h}$ to below $0.5 \mathrm{ng} / \mathrm{mL}$ [16]. JWH-018 and other synthetic cannabinoids are oxidized by specific cytochrome P450 enzymes [17] and excreted in the urine as glucuronic acid conjugates, while the parent compounds are normally not present in the urine $[18,19]$.

Reported clinical symptoms of "spice" intoxication include tachycardia, nausea and vomiting as well as psychic effects such as agitation, drowsiness, dizziness and hallucinations [16,20-22]. This means that synthetic cannabinoid intake is incompatible with safe driving, and according to Danish law [23], the legal traffic limit for synthetic cannabinoids in blood is $0.0005 \mathrm{mg} / \mathrm{kg}(\sim 0.5 \mathrm{ng} / \mathrm{mL})$

The easy availability of these compounds over the internet and the possibility of circumventing routine drug screening assays suggest that driving under the influence of synthetic cannabinoids could pose a problem, but few reports have been published addressing this issue. Strano-Rossi et al. screened 400 oral samples collected from random traffic controls, but detected no synthetic cannabinoids [11]. However, Musshoff et al. recently published a total of seven traffic cases, in which a number of synthetic cannabinoids were identified in the blood [20].

In this study, we investigated the presence of synthetic cannabinoids among Danish drivers. An automated SPE and LC-MS/MS screening method 
for the detection of 13 synthetic cannabinoids in whole blood was developed and validated. The method was used to screen 393 Danish traffic cases from 2012, where the driver was suspected of driving under the influence of drugs (DUID). The method was also applied to a clinical intoxication case, where synthetic cannabinoid intake was suspected.

\section{MATERIALS AND METHODS}

\subsection{Chemicals and standards}

LC-MS grade acetonitrile (ACN), methanol $(\mathrm{MeOH})$, and water were from Fisher Scientific (Leicestershire, UK). Glacial acetic acid (HAc) was from Merck (Darmstadt, Germany). Analytical standards were obtained from multiple chemical suppliers: HU-210, JWH-073 and JWH-122 were from LGC (Teddington, UK), JWH-015 was from Sigma-Aldrich (St. Louis, MO, USA), and JWH-018 from Lipomed (Arlesheim, Germany). JWH-018-d11 was from Chiron (Trondheim, Norway). A number of compounds were obtained from powders seized by the Danish customs authorities: AKB-48, AM-2201, MAM2201, JWH-182, JWH-203, JWH-210, JWH-370, and UR-144. The compounds were identified in-house by GC-MS, and for the majority of compounds also by NMR. The chemical structures of these compounds are shown in Appendix 1.

\subsection{Blood samples}

Venous whole blood samples were obtained from persons suspected by the police of driving under the influence of drugs (DUID), and stored in collection tubes containing $\mathrm{NaF}$ and potassium oxalate (Venosafe, Terumo Europe N.V.). Blood samples used for the validation were obtained from traffic cases. The quality controls (QCs) were made in pooled whole blood obtained from the Blood Bank at Copenhagen University Hospital (Copenhagen, Denmark). All samples were stored at $-20^{\circ} \mathrm{C}$ and thawed immediately before solid-phase extraction (SPE).

\subsection{Preparation of spiked blood samples}

All analytical standards were dissolved in methanol at a concentration of 100 or $1000 \mathrm{mg} / \mathrm{l}$, and subsequently stored in ampoules at $-25^{\circ} \mathrm{C}$. The standard solutions were mixed to generate working solutions of $1000 \mathrm{ng} / \mathrm{mL}$ and $50 \mathrm{ng} / \mathrm{mL}$ in water: $\mathrm{MeOH}(50: 50, \mathrm{v} / \mathrm{v})$. The working solutions were spiked into whole blood to generate $\mathrm{QC}$ low $(5 \mathrm{ng} / \mathrm{mL})$ and $\mathrm{QC}$ high $(50 \mathrm{ng} / \mathrm{mL})$ as well as the other concentrations used in the validation. The volumepercentage of methanol in the samples did not exceed $10 \%$. The internal standard (IS) solution consisted of JWH-018-d11 dissolved in water: $\mathrm{MeOH}$ $(50: 50 \mathrm{v} / \mathrm{v})$ at a concentration of $50 \mathrm{ng} / \mathrm{mL}$.

\subsection{Sample preparation}

Fully automated sample preparation was performed on a Freedom EVO 200 robotic platform (Tecan, Männerdorf, Switzerland) using Strata X-C SPE 96-well plates $30 \mathrm{mg} /$ well (Phenomenex, Torrance, CA, USA) as previously described by Andersen et al. [24]. The entire sample preparation took approximately $3 \mathrm{~h}$, and consisted of an initial protein precipitation step followed by SPE, evaporation and reconstitution in mobile phase. Briefly, an aliquot of whole blood $(200 \mu \mathrm{L})$ was transferred to a 96 well plate placed on a balance (XP203S, Mettler Toledo, Schwerzenbach, Switzerland). The registered weight of each aliquot was used in the later processing of data adjusting for the transferred sample mass. The IS-solution $(20 \mu \mathrm{L})$ was added to each sample before protein precipitation, for which $15 \% \mathrm{MeOH}$ in ACN $(600 \mu \mathrm{L})$ was used. After centrifugation at $1000 \mathrm{~g}$ for $10 \mathrm{~min}$, an aliquot $(600 \mu \mathrm{L})$ of the supernatant was mixed with $900 \mu \mathrm{L}$ of $0.1 \mathrm{M} \mathrm{HAc}$ and loaded onto the SPE-columns, which had been preconditioned with $15 \% \mathrm{MeOH}$ in $\mathrm{ACN}(800 \mu \mathrm{L})$, and subsequently with $0.1 \mathrm{M} \mathrm{HAc}(800 \mu \mathrm{L})$. The washing steps consisted of $700 \mu \mathrm{L}$ of $0.1 \mathrm{M} \mathrm{HAc}$ followed by an equal volume of $0.1 \mathrm{M} \mathrm{HAc}$ in $\mathrm{ACN}(70: 30 \% \mathrm{v} / \mathrm{v})$. Elution was performed using two portions ( $250 \mu \mathrm{L}$ each) of $2 \% \mathrm{HAC}$ in $\mathrm{ACN}$. The eluate was evaporated to dryness under a stream of nitrogen at $40^{\circ} \mathrm{C}$ and reconstituted in $100 \mu \mathrm{L}$ of $1 \% \mathrm{HAc}$ in water: $\mathrm{MeOH}$ $(30: 70 \% \mathrm{v} / \mathrm{v})$.

\section{$2.5 \mathrm{LC}-\mathrm{MS} / \mathrm{MS}$}

The LC-MS/MS system consisted of a Micromass Quattro Micro triple quadrupole mass spectrometer (Waters, Milford, MA, USA) interfaced to an Agilent 1100 Series HPLC system upgraded with a 1260 series autosampler (Agilent Technologies, Wilmington, DE, USA). Chromatographic separation was performed on a Kinetex $2.6 \mu \mathrm{m}$ phenyl-hexyl $50 \times 2.1 \mathrm{~mm}$ column (Phenomenex, Torrance, CA. USA) using $1 \% \mathrm{HAc}$ in water (solvent A) and $\mathrm{MeOH}$ (solvent $\mathrm{B}$ ) as mobile phases. The gradient had a total run-time of 13 min starting at $70 \%$ B linearly increasing to $90 \%$ B over $7.0 \mathrm{~min}$, isocratic for $1.5 \mathrm{~min}$ before returning to $70 \% \mathrm{~B}$ in $0.5 \mathrm{~min}$. The system was re-equilibrated for $4.0 \mathrm{~min}$ with $70 \% \mathrm{~B}$. The flow rate was $0.3 \mathrm{~mL} / \mathrm{min}$, the column temperature was $30^{\circ} \mathrm{C}$, and the injection volume was $20 \mu \mathrm{L}$. The screening was performed using multiple reaction monitoring (MRM) in positive electrospray ionization (ESI) mode. The capillary voltage was set to $1.0 \mathrm{kV}$ and the source block temperature was set to $120^{\circ} \mathrm{C}$. The desolvation gas (nitrogen) was heated to $350^{\circ} \mathrm{C}$ and delivered at a flow rate of $800 \mathrm{~L} / \mathrm{h}$, while the cone gas (nitrogen) was delivered at $30 \mathrm{~L} / \mathrm{h}$. The collision gas (argon) pressure was maintained at approx. $3 \cdot 10^{-3} \mathrm{mbar}$ in the collision cell. The data acquisition was controlled with MassLynx 4.1, while the data were processed with the TargetLynx software (Waters, Milford, MA, USA).

Two transitions were monitored for each of the 13 analytes and one for the IS. The chosen transitions, collision energies, and retention times (RT) are listed in Table 1. The dwell time for each transition ranged between $0.017 \mathrm{~s}$ and $0.04 \mathrm{~s}$ with an inter-scan and -channel delay of $0.05 \mathrm{~s}$.

\subsection{Validation}

The validation of the method included selectivity, limit of detection (LOD), and recovery of the extraction procedure. The validation was performed on a single day using two sample preparation runs.

\subsubsection{Identification criteria}

The criteria for a positive identification were based on guidelines proposed by Rivier [25]: i) RT within $\pm 2 \%$ from a reference standard; ii) ion ratio of the qualifier ion to the quantifier ion (base peak) within $\pm 10 \%, \pm 12.5 \%$ and \pm $15 \%$ that of the reference standard for relative ion intensities $<25 \%,<50 \%$ and $\geq 25 \%$, and $>50 \%$ respectively; and iii) a signal-to-noise $(\mathrm{S} / \mathrm{N})$ ratio $>3$. 


\subsubsection{Selectivity}

Eight blank blood samples from different donors were analyzed to evaluate interference from endogenous substances. The selectivity of the method was further analyzed in two samples spiked with a mixture of 200 therapeutic drugs and drugs of abuse including cocaine, codeine, amphetamine, and various benzodiazepines $(100 \mathrm{ng} / \mathrm{mL})$. Finally, two blank samples spiked only with the IS (zero blanks) were analyzed. Adequate selectivity was achieved when none of the included analytes were identified based on the identification criteria.

\subsubsection{Limit of detection}

The LOD was determined by spiking eight different blank blood samples with a mixture of synthetic cannabinoids at seven concentration levels. The levels were $0.1,0.25,0.5,1,2.5,5$ and $10 \mathrm{ng} / \mathrm{mL}$ for all analytes except AKB-48 and HU-210, which due to sensitivity issues were included at ten times higher concentration at each level. The LOD for an analyte was defined to be the concentration level where the identification criteria were fulfilled for all eight samples.

\subsubsection{Extraction recovery}

Extraction recovery (RE), was evaluated by comparing the peak areas of the analytes spiked after (B), and before $(C)$ the extraction, and calculated according to $\operatorname{RE}(\%)=C / B$. This procedure was performed for two concentration levels ( 5 and $50 \mathrm{ng} / \mathrm{mL}$ ) in 4 different blank blood samples.

\subsubsection{Carry-over}

Carry-over was investigated by injecting a sample containing a high concentration of synthetic cannabinoids $(100 \mathrm{ng} / \mathrm{mL})$, followed by repeated injections of a blank sample.

\section{Table 1. MRM settings.}

\begin{tabular}{|c|c|c|c|c|c|c|}
\hline Analyte & $\begin{array}{l}\text { Q1 } \\
\mathrm{m} / \mathrm{z} \\
\end{array}$ & $\begin{array}{l}\mathbf{Q 3}^{\prime} \\
\mathrm{m} / \mathrm{z} \\
\end{array}$ & Cone energy (V) & Collision energy (eV) & RT (min) & $q / Q$ ratio (\%) \\
\hline \multirow[t]{2}{*}{ AKB-48 } & \multirow[t]{2}{*}{366.3} & 135.1 & 30 & 20 & \multirow[t]{2}{*}{6.4} & \multirow[t]{2}{*}{8.0} \\
\hline & & 79.0 & 30 & 50 & & \\
\hline \multirow[t]{2}{*}{ AM-2201 } & \multirow[t]{2}{*}{360.2} & 155.1 & 36 & 24 & \multirow[t]{2}{*}{3.9} & \multirow[t]{2}{*}{30} \\
\hline & & 127.1 & 36 & 44 & & \\
\hline \multirow[t]{2}{*}{ HU-210 } & \multirow[t]{2}{*}{387.3} & 71.1 & 30 & 24 & \multirow[t]{2}{*}{5.5} & \multirow[t]{2}{*}{43} \\
\hline & & 57.0 & 30 & 26 & & \\
\hline \multirow[t]{2}{*}{ JWH-015 } & \multirow[t]{2}{*}{328.2} & 155.1 & 34 & 22 & \multirow[t]{2}{*}{3.3} & \multirow[t]{2}{*}{53} \\
\hline & & 127.1 & 34 & 42 & & \\
\hline \multirow[t]{2}{*}{ JWH-018 } & \multirow[t]{2}{*}{342.2} & 155.1 & 32 & 24 & \multirow[t]{2}{*}{5.1} & \multirow[t]{2}{*}{51} \\
\hline & & 127.1 & 32 & 45 & & \\
\hline \multirow[t]{2}{*}{ JWH-073 } & \multirow[t]{2}{*}{328.2} & 155.1 & 34 & 22 & \multirow[t]{2}{*}{4.2} & \multirow[t]{2}{*}{53} \\
\hline & & 127.1 & 34 & 42 & & \\
\hline \multirow[t]{2}{*}{ JWH-122 } & \multirow[t]{2}{*}{356.2} & 169.1 & 32 & 24 & \multirow[t]{2}{*}{5.9} & \multirow[t]{2}{*}{54} \\
\hline & & 141.1 & 32 & 40 & & \\
\hline \multirow[t]{2}{*}{ JWH-182 } & \multirow[t]{2}{*}{384.2} & 197.1 & 36 & 26 & \multirow[t]{2}{*}{7.3} & \multirow[t]{2}{*}{58} \\
\hline & & 141.0 & 36 & 46 & & \\
\hline JWH-203 & 340.2 & 125.0 & 36 & 24 & 4.2 & 12 \\
\hline & & 89.1 & 36 & 66 & & \\
\hline JWH-210 & 370.2 & 183.1 & 38 & 24 & 6.7 & 19 \\
\hline & & 155.1 & 38 & 46 & & \\
\hline JWH-370 & 382.2 & 155.1 & 29 & 20 & 6.4 & 39 \\
\hline & & 127.1 & 29 & 48 & & \\
\hline MAM-2201 & 374.2 & 169.1 & 42 & 25 & 4.7 & 86 \\
\hline & & 141.1 & 42 & 44 & & \\
\hline UR-144 & 312.2 & 125.1 & 38 & 22 & 4.7 & 15 \\
\hline & & 144.0 & 38 & 36 & & \\
\hline JWH-018-d11 (IS) & 353.3 & 155.1 & 32 & 24 & 5.1 & - \\
\hline
\end{tabular}




\section{RESULTS}

\subsection{Validation}

The method showed satisfactory selectivity as none of the analytes were detected in the blank samples or in the blank samples spiked with a panel of common drugs of abuse and therapeutic drugs. There was no interference from the internal standard. The LOD was $0.1-0.25 \mathrm{ng} / \mathrm{mL}$ for most JWH-type synthetic cannabinoids and AM-2201, $2.5 \mathrm{ng} / \mathrm{mL}$ for AKB-48 and MAM-2201, and $25 \mathrm{ng} / \mathrm{mL}$ for HU-210 as shown in Table 2. A number of compounds, e.g., JWH-018, could be positively identified in all 8 samples at the lowest concentration level used. The extraction recovery ranged from $59-78 \%$, with HU-210 having the lowest recovery. There was no carry-over. Some synthetic cannabinoids were from seized material. Even though materials from illegal sources are often of high purity [26], it is possible that the compounds were not pure. This would, however, likely lead to the apparent LOD being higher than the real LOD.

\subsection{Method application}

The Section of Forensic Chemistry, Copenhagen University receives blood samples from persons suspected of driving under the influence of drugs (DUID) in the eastern part of Denmark. The new method was applied to 393 consecutive forensic traffic cases from 2012. No synthetic cannabinoids were identified. As part of routine analysis, 118 (30\%) of the cases were investigated for only THC, and 99 (84\%) of these samples were reported positive above the Danish legal limit $(0.0015 \mathrm{mg} / \mathrm{kg}$ with correction for analytical uncertainty). 254 cases (65\%) were screened both for THC and a number of drugs of abuse and therapeutic drugs. THC was the most common drug reported in 105 (41\%) of these cases, follow by amphetamine $(12 \%)$, cocaine $(11 \%)$, methadone $(10 \%)$, and morphine (4\%). Benzodiazepines as a group were detected above the legal limit in 61 cases (22\%) with clonazepam being the most frequently detected drug. These prevalences are roughly the same as our findings from 2011 (27). In 107 (27\%) of the 393 cases no drugs were detected above the legal limit.

\subsection{Clinical case}

A 40-year old male was admitted to the emergency department at Bispebjerg University Hospital (Copenhagen, Denmark) after smoking the spice-product "doob". The elapsed time from smoking to hospital admission was unknown. He was found drowsy and in a slow-reacting condition at home, but was otherwise alert upon arrival to the emergency department (Glasgow Coma Scale of 14). Physical examination revealed normal vital signs except for tachycardia (98 beats/min). Serum and urine were collected at admission. Twenty hours after admission he was fully awake without intoxication symptoms and was discharged.

An opened package of "doob" was found at his home, and the patient acknowledged smoking a self-estimated $0.5 \mathrm{~g}$ together with concomitant intake of a-methyltryptamine (AMT) and a substance he described as benzodiazepine-like. GC-MS analysis of the content of the package identified the synthetic cannabinoids 1-(5-fluoropentyl)-3-(1-naphthoyl)indole (AM-2201) and trace amounts of 1-[(N-methylpiperidin-2-yl)methyl]-3-(2iodobenzoyl)indole (AM-2233), in agreement with a label on the package.

The presented screening method was applied to the serum sample, and AM-2201 was identified (Figure 1). As the response for AM-2201 was found to be

Table 2. Validation data on LOD and extraction recovery (RE)

\begin{tabular}{|c|c|c|c|c|c|c|c|c|c|c|}
\hline \multirow[b]{2}{*}{ Compounds } & \multicolumn{7}{|c|}{ Concentration levels (ng/mL) } & \multirow[b]{2}{*}{ LOD (ng/mL) } & \multicolumn{2}{|c|}{$\%$ RE } \\
\hline & 0.10 & 0.25 & 0.50 & 1.0 & 2.5 & 5.0 & 10.0 & & $5 \mathrm{ng} / \mathrm{mL}$ & $50 \mathrm{ng} / \mathrm{mL}$ \\
\hline AKB-48" & $6 / 8^{*}$ & $8 / 8$ & $8 / 8$ & $8 / 8$ & $8 / 8$ & $8 / 8$ & $8 / 8$ & 2.5 & 63 & 74 \\
\hline AM 2201 & $7 / 8$ & $8 / 8$ & $8 / 8$ & $8 / 8$ & $8 / 8$ & $8 / 8$ & $8 / 8$ & 0.25 & 67 & 74 \\
\hline HU-210" & $1 / 8$ & $3 / 8$ & $5 / 8$ & $6 / 8$ & $8 / 8$ & $8 / 8$ & $8 / 8$ & 25 & N.A & 59 \\
\hline JWH-015 & $8 / 8$ & $8 / 8$ & $8 / 8$ & $8 / 8$ & $8 / 8$ & $8 / 8$ & $8 / 8$ & 0.10 & 64 & 72 \\
\hline JWH-018 & $8 / 8$ & $8 / 8$ & $8 / 8$ & $8 / 8$ & $8 / 8$ & $8 / 8$ & $8 / 8$ & 0.10 & 66 & 73 \\
\hline JWH-073 & $7 / 8$ & $8 / 8$ & $8 / 8$ & $8 / 8$ & $8 / 8$ & $8 / 8$ & $8 / 8$ & 0.25 & 66 & 74 \\
\hline JWH-122 & $8 / 8$ & $8 / 8$ & $8 / 8$ & $8 / 8$ & $8 / 8$ & $8 / 8$ & $8 / 8$ & 0.10 & 65 & 73 \\
\hline JWH-182 & $7 / 8$ & $8 / 8$ & $8 / 8$ & $8 / 8$ & $8 / 8$ & $8 / 8$ & $8 / 8$ & 0.25 & 63 & 74 \\
\hline JWH-203 & $8 / 8$ & $8 / 8$ & $8 / 8$ & $8 / 8$ & $8 / 8$ & $8 / 8$ & $8 / 8$ & 0.10 & 66 & 77 \\
\hline JWH-210 & $7 / 8$ & $8 / 8$ & $8 / 8$ & $8 / 8$ & $8 / 8$ & $8 / 8$ & $8 / 8$ & 0.25 & 65 & 70 \\
\hline JWH-370 & $8 / 8$ & $8 / 8$ & $8 / 8$ & $8 / 8$ & $8 / 8$ & $8 / 8$ & $8 / 8$ & 0.10 & 67 & 78 \\
\hline MAM 2201 & $4 / 8$ & $5 / 8$ & $7 / 8$ & $6 / 8$ & $8 / 8$ & $8 / 8$ & $8 / 8$ & 2.5 & 65 & 70 \\
\hline UR-144 & $6 / 8$ & $8 / 8$ & $8 / 8$ & $8 / 8$ & $8 / 8$ & $8 / 8$ & $8 / 8$ & 0.25 & 61 & 66 \\
\hline
\end{tabular}


linear in the range from 0.25 to $10 \mathrm{ng} / \mathrm{mL}\left(R^{2}>0.99\right.$, weighting $\left.1 / \mathrm{x}\right)$ during the validation, the concentration of AM-2201 in the serum was semi-quantitatively determined to be $3.1 \mathrm{ng} / \mathrm{mL}$ by comparing the response to the response from the QC low ( $5 \mathrm{ng} / \mathrm{mL}$ ). Additionally, AMT and two isomers of APB (2-aminopropyl) benzofuran were detected in the serum with one isomer being 5-APB.

In urine, two isomeric hydroxy metabolites of AM-2201 were identified using an in-house developed high-resolution accurate mass (HRAM) method (unpublished). One was verified by reference material to be $\mathrm{AM}-2201-\mathrm{N}-(4-\mathrm{OH})$, while the identity of the second isomer could not be unambiguously determined. We also detected JWH-018-N-pentanoic acid, an N-hydroxy JWH018 isomer, and, tentatively, JWH-072-N-propanoic acid. Neither AM-2201 nor JWH-018 was detected in the urine.

\section{DISCUSSION}

In the present study we screened nearly 400 Danish DUID samples from 2012, but did not identify synthetic cannabinoids in the traffic samples. This study is the first investigation of its kind in Denmark and the results suggest that the prevalence of driving under the influence of synthetic cannabinoids is low. This conclusion is similar to that of an Italian study using 400 samples from random traffic controls [11]. In a case series article from 2012, Musshoff et al. reported 7 cases of driving under the influence of synthetic cannabinoids, but unfortunately it was not stated how many samples were screened in total [20].

The analytes included in the method cover the majority of synthetic cannabinoids identified in material seized by the Danish customs authorities during 2011-2012 [28]. In the report by Musshoff et al., the most frequently detected compounds were AM-2201, JWH-018, JWH-210, JWH-122, and JWH307 [20]. The blood concentrations measured in the latter study were all above $0.5 \mathrm{ng} / \mathrm{mL}$ with typical concentrations in the range of $1-8 \mathrm{ng} / \mathrm{mL}$ [20].Thus, the analytical method presented here has an acceptable sensitivity for most JWHtype synthetic cannabinoids to allow for its use in screening of traffic cases.

We identified AM-2201 in a clinical intoxication case, but due to the patient's intake of multiple drugs, it was not possible to conclude that AM-2201 alone caused the intoxication. We identified two previously described [19] $\mathrm{N}$-hydroxy metabolites of AM-2201 in the urine. AM-2201 has been suggested to undergo enzymatic defluorination to produce JWH-018 [19], which could explain the presence of JWH-018 N-hydroxy and $\mathrm{N}$-pentanoic acid metabolites in the urine. We also tentatively identified JWH-072 N-propanoic acid, which has been suggested to be a common metabolite for selected naphthoylindolebased synthetic cannabinoids [29].

Our section also receives postmortem blood samples if drug intake is suspected to be involved in or to be the cause of death, and it could be interesting in the future to investigate these samples for synthetic cannabinoids. Shanks et al. have recently identified JWH-018 and JWH-073 in high concentrations in such postmortem cases [9].

\section{ACKNOWLEDGEMENT}

Camilla Bjørnbak, MD at the Emergency Room at Bispebjerg University Hospital is acknowledged for obtaining the clinical case samples.

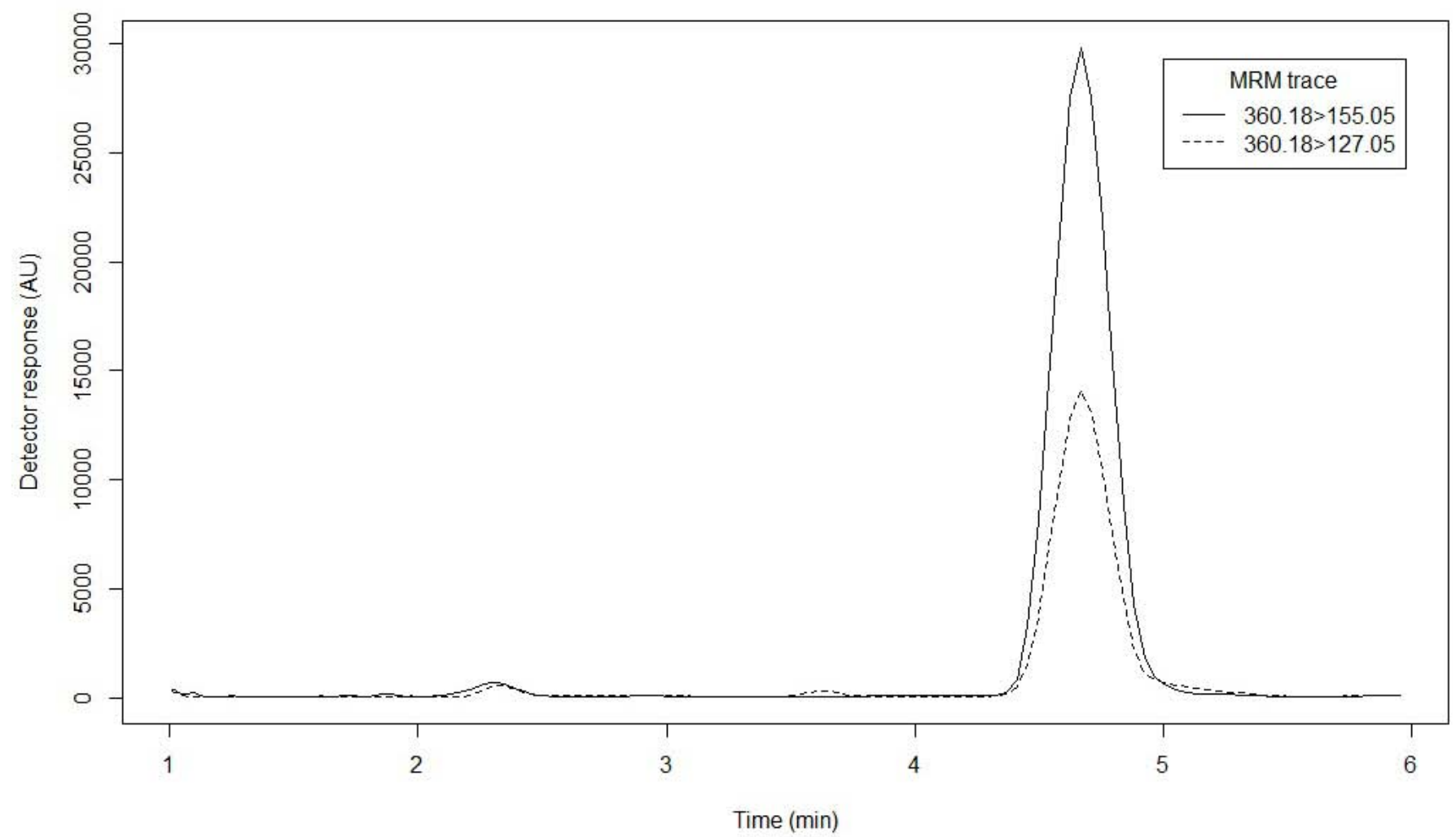

Figure 1. MRM traces showing the presence of AM-2201 in the serum of an intoxicated patient. The sample underwent automated SPE and sample extract was analyzed by LC-MS/MS. The concentration was semi-quantitatively determined to be $3.1 \mathrm{ng} / \mathrm{mL}$ 


\section{REFERENCES}

[1] Pertwee R.G., Ligands that target cannabinoid receptors in the brain: from THC to anandamide and beyond, Addict. Biol., 2008, 13, 147-159

[2] Auwarter V., Dresen S., Weinmann W., Muller M., Putz M., Ferreiros N., 'Spice' and other herbal blends: harmless incense or cannabinoid designer drugs?, J. Mass Spectrom., 2009, 44, 832-837

[3] Uchiyama N., Kikura-Hanajiri R., Kawahara N., Haishima Y., Goda Y., Identification of a cannabinoid analog as a new type of designer drug in a herbal product, Chem. Pharm. Bull. (Tokyo), 2009, 57, 439-441

[4] Dresen S., Ferreiros N., Putz M., Westphal F., Zimmermann R., Auwarter V., Monitoring of herbal mixtures potentially containing synthetic cannabinoids as psychoactive compounds, J. Mass Spectrom., 2010, 45, 1186-1194

[5] Shanks K.G., Dahn T., Behonick G., Terrell A., Analysis of first and second generation legal highs for synthetic cannabinoids and synthetic stimulants by ultra-performance liquid chromatography and time of flight mass spectrometry, J. Anal. Toxicol., 2012, 36, 360-371

[6] Uchiyama N., Kawamura M., Kikura-Hanajiri R., Goda Y., URB-754: a new class of designer drug and 12 synthetic cannabinoids detected in illegal products, Forensic Sci. Int., 2013, 227, 21-32

[7] European Monitoring Centre for Drugs and Drug Addiction, European Drug Report 2013: Trends and Developments. 2013, http://www.emcdda.europa.eu/ publications/edr/trends-developments/2013

[8] Kacinko S.L., Xu A., Homan J.W., McMullin M.M., Warrington D.M., Logan B.K., Development and validation of a liquid chromatography-tandem mass spectrometry method for the identification and quantification of JWH-018, JWH073, JWH-019, and JWH-250 in human whole blood, J. Anal. Toxicol., 2011, 35, 386-393

[9] Shanks K.G., Dahn T., Terrell A.R., Detection of JWH-018 and JWH-073 by UPLC-MS MS in postmortem whole blood casework, J. Anal. Toxicol., 2012, 36, 145-152

[10] Dresen S., Kneisel S., Weinmann W., Zimmermann R., Auwarter V., Development and validation of a liquid chromatography-tandem mass spectrometry method for the quantitation of synthetic cannabinoids of the aminoalkylindole type and methanandamide in serum and its application to forensic samples, J. Mass Spectrom., 2011, 46, 163-171

[11] Strano-Rossi S., Anzillotti L., Castrignano E., Romolo F.S., Chiarotti M., Ultra high performance liquid chromatography-electrospray ionization-tandem mas spectrometry screening method for direct analysis of designer drugs, "spice" and stimulants in oral fluid, J. Chromatogr. A, 2012, 1258, 37-42

[12] Kneisel S., Auwarter V., Kempf J., Analysis of 30 synthetic cannabinoids in oral fluid using liquid chromatography-electrospray ionization tandem mass spectrometry, Drug Test. Anal., 2013,5,657-69, DOI: 10.1002/dta 1429

[13] Moran C.L., Le V.H., Chimalakonda K.C., Smedley A.L., Lackey F.D., Owen S.N.et al., Quantitative measurement of JWH-018 and JWH-073 metabolites excreted in human urine, Anal. Chem., 2011, 83, 4228-4236

[14] Hutter M., Broecker S., Kneisel S., Auwarter V., Identification of the major urinary metabolites in man of seven synthetic cannabinoids of the aminoalkylindole type present as adulterants in 'herbal mixtures' using LC-MS/MS techniques, J. Mass Spectrom., 2012, 47, 54-65
[15] Wohlfarth A., Scheidweiler K.B., Chen X., Liu H.F., Huestis M.A., Qualitative confirmation of 9 synthetic cannabinoids and 20 metabolites in human urine using LC-MS/MS and library search, Anal. Chem., 2013, 85, 3730-3738

[16] Teske J., Weller J.P., Fieguth A., Rothamel T., Schulz Y., Troger H.D., Sensitive and rapid quantification of the cannabinoid receptor agonist naphthalen1-yl-(1-pentylindol-3-yl)methanone (JWH-018) in human serum by liquid chromatography-tandem mass spectrometry, J. Chromatogr. B Analyt. Technol. Biomed. Life Sci., 2010, 878, 2659-2663

[17] Chimalakonda K.C., Seely K.A., Bratton S.M., Brents L.K., Moran C.L., Endres G.W.et al., Cytochrome P450-mediated oxidative metabolism of abused synthetic cannabinoids found in K2/Spice: identification of novel cannabinoid receptor ligands, Drug Metab Dispos., 2012, 40, 2174-2184

[18] Sobolevsky T., Prasolov I., Rodchenkov G., Detection of JWH-018 metabolites in smoking mixture post-administration urine, Forensic Sci. Int., 2010, 200, 141-147

[19] Sobolevsky T., Prasolov I., Rodchenkov G., Detection of urinary metabolites of AM-2201 and UR-144, two novel synthetic cannabinoids, Drug Test. Anal., 2012 DOI: $10.1002 /$ dta. 1418

[20] Musshoff F., Madea B., Kernbach-Wighton G., Bicker W., Kneisel S., Hutter M.et al., Driving under the influence of synthetic cannabinoids ("Spice"): a case series, Int. J. Legal Med., 2013, DOI: 10.1007/s00414-013-0864-1

[21] Hermanns-Clausen M., Kneisel S., Szabo B., Auwarter V., Acute toxicity due to the confirmed consumption of synthetic cannabinoids: clinical and laboratory findings, Addiction, 2013, 108, 534-544

[22] Gunderson E.W., Haughey H.M., Ait-Daoud N., Joshi A.S., Hart C.L., "Spice" and "K2" herbal highs: a case series and systematic review of the clinical effects and biopsychosocial implications of synthetic cannabinoid use in humans, Am. J. Addict., 2012, 21, 320-326

[23] Bekendtgørelse om ændring af bekendtgørelse om klassificering af færdselssikkerhedsfarlige stoffer, bilag 1, https://www.retsinformation.dk/Forms/ R0710.aspx?id=138271\#B1

[24] Andersen D., Rasmussen B., Linnet K., Validation of a fully automated robotic setup for preparation of whole blood samples for LC-MS toxicology analysis, J. Anal. Toxicol., 2012, 36, 280-287

[25] Rivier L., Criteria for the identification of compounds by liquid chromatographymass spectrometry and liquid chromatography-multiple mass spectrometry in forensic toxicology and doping analysis, Analytica Chimica Acta, 2003, 492, 69-82

[26] Ginsburg B.C., McMahon L.R., Sanchez J.J., Javors M.A., Purity of synthetic cannabinoids sold online for recreational use, J. Anal. Toxicol., 2012, 36, 66-68

[27] Pedersen A.J., Dalsgaard P.W., Rode A.J., Rasmussen B.S., Muller I.B., Johansen S.S.et al., Screening for illicit and medicinal drugs in whole blood using fully automated SPE and ultra-high-performance liquid chromatography with TOF-MS with data-independent acquisition, J. Sep. Sci., 2013, 36, 2081-2089, DOI: 10.1002/jssc.201200921

[28] Sundhedsstyrelsen, Illegale stoffer i Danmark, Årsrapport 2012. 2013

[29] Lovett D.P., Yanes E.G., Herbelin T.W., Knoerzer T.A., Levisky J.A., Structure elucidation and identification of a common metabolite for naphthoylindolebased synthetic cannabinoids using LC-TOF and comparison to a synthetic reference standard, Forensic Sci. Int., 2013, 226, 81-87 
APPENDIX 1 CHEMICAL STRUCTURES OF ANALYTES AND INTERNAL STANDARD INCLUDED IN THE METHOD

AKB-48<smiles>CCCCCn1nc(C(=O)NC23CC4CC(CC(C4)C2)C3)c2ccccc21</smiles>

JWH-015<smiles>CCCn1c(C)c(C(=O)c2cccc3ccccc23)c2ccccc21</smiles>

JWH-122<smiles>CCCCCn1cc(C(=O)c2ccc(C)c3ccccc23)c2ccccc21</smiles>

JWH-370<smiles>CCCCCn1cc(C(=O)c2cccc3ccccc23)cc1-c1ccccc1C</smiles>

AM-2201

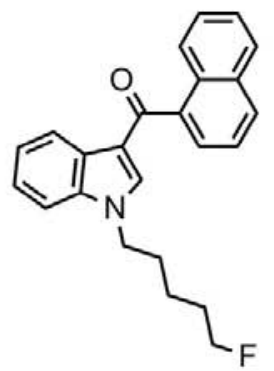

JWH-018<smiles>CCCCCn1cc(C(=O)c2cccc3ccccc23)c2ccccc21</smiles>

JWH-182

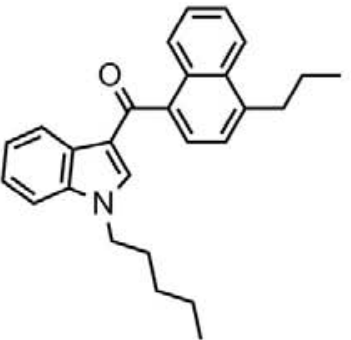

MAM-2201<smiles>Cc1ccc(C(=O)c2cn(CCCCCF)c3ccccc23)c2ccccc12</smiles>

HU-210<smiles>CCCCCCC(C)(C)c1cc(O)c2c(c1)OC(C)(C)C1CC=C(CO)CC21</smiles>

JWH-018-d11

JWH-073<smiles>[2H]C([2H])([2H])C([2H])([2H])C([2H])([2H])C([2H])([2H])n1cc(C(=O)c2cccc3ccccc23)c2ccccc21</smiles>

JWH-203<smiles>CCCCn1cc(C(=O)c2cccc3ccccc23)c2ccccc21</smiles>

JWH-210<smiles>CCCCCn1cc(C(=O)c2ccc(CC)c3ccccc23)c2ccccc21</smiles>

UR-144<smiles>CCCCCn1cc(C(=O)C2C(C)(C)C2(C)C)c2ccccc21</smiles> 